Guest Lecture Series of the Office of the Prosecutor

\author{
W. J. Fenrick ${ }^{1}$ \\ "Crimes in combat: the relationship between \\ crimes against humanity and war crimes"
}

5 March 2004

The Hague

\footnotetext{
${ }^{1}$ Senior Legal Adviser, ICTY-OTP. These remarks are made by the author in his personal capacity and do not necessarily reflect the views of the ICTY-OTP or the United Nations.
} 
The way in which international tribunals address crimes committed in combat will have a substantial impact on perceptions of the tribunals by national foreign ministries and defence departments and may also have a substantial impact on the development of international humanitarian law (IHL) as well as the development of international criminal law. The ICC may, of course, simply adopt the approach taken by most tribunals in the past, including those which adjudicated the post World War II war crimes cases, and ignore offences committed in combat. Defensible arguments can be made that prosecutors can and must choose which cases to prosecute from an abundance of atrocities and that it is preferable to choose cases involving clear cut crimes and generally agreed morally wrong acts. I have taken part in one conference in which a respected speaker suggested that crimes committed in combat such as unlawful attacks should be regarded as non-justiciable because they would be too difficult to prosecute.

If, however, the ICC-OTP does decide to prosecute for crimes committed in combat, it must develop the ability to present an honest and accurate picture of what happened during combat and the ability to assist the court to differentiate between lawful and unlawful acts in circumstances where both might result in death, injury and destruction. Unfortunately, war is a brutal business. Until it is abolished, one must accept that the purpose of the body of law which purports to regulate combat is to limit human suffering, not to eliminate it. Indeed, legal arguments which purport to eliminate violence in armed conflict may result in undermining the applicable law and rendering it ineffective. For example, arguing that any civilian casualties are too many civilian casualties no matter how important the military objective being attacked would be counterproductive as such a standard, no matter how desirable in the abstract, would not be viable in military operations at the present time.

I would suggest that a defensible and realistic objective for international prosecutors handling combat related cases is to stretch the legal envelope, to pursue legal standards slightly in advance of state practice. It is not to rip the end off the envelope in pursuit of combat standards which turn all persons who fight wars, even those from law-sensitive states acting in good faith, into criminals. My reflections on the legal relationship between crimes against humanity and war crimes occurring in a combat context and on how we have learned, and continue to learn, to handle combat related issues in the ICTY-OTP may be of assistance to you as you begin to grapple with similar issues before the ICC. My reflections will focus in particular on the war crime of unlawful attacks on civilians and the crime against humanity of persecution.

\section{War crimes}

The concept of a war crime has been a part of international law for many centuries. In brief, war crimes are: (a) one of a list of acts generally prohibited by treaty but occasionally prohibited by customary law, and (b) committed during an armed conflict. Some of these acts are prohibited in international conflicts alone, some in internal conflicts alone and some in all conflicts. The prohibited acts must be committed (c) by a perpetrator linked to one side of the conflict, and (d) against a victim who is neutral or linked to the other side of the conflict. The body of treaty and customary law which provides the legal underpinnings for the war crimes concept and which is referred to variously as the law of war, the law of armed conflict, and IHL is quite voluminous. The standard compilation of relevant treaty texts, Schindler \& Toman, The Laws of Armed Conflicts, includes over 1000 pages in its $3^{\text {rd }}$ edition of 1988 
Some enumerated war crimes are listed in Art. 2 and 3 of the ICTY Statute. In addition, we at the ICTY can prosecute for unenumerated war crimes under Art. 3 of the ICTY Statute provided certain tests set out in paras 94 and 143 of the Tadic Jurisdiction Appeal are met, in particular: (a) the violation must constitute an infringement of a rule of international humanitarian law, (b) the rule must be customary in nature or, if the rule has a treaty law basis, the treaty must be binding on the parties at the time of the incident and the rule must not conflict with a peremptory norm of international law, (c) the violation must be "serious", that is to say, it must constitute a breach of a rule protecting important values, and the breach must involve important consequences for the victim, and (d) the violation of the rule must entail, under customary or treaty law, the individual criminal responsibility of the person breaching the rule.

Under the ICC Statute, of course, all punishable war crimes are explicitly enumerated in Art. 8. There is no provision for the prosecution of unenumerated offences. The ICC Statute differentiates between war crimes committed in international conflicts and in what would appear to be two types of internal conflicts, a Common Article 3 conflict (Art. 8(2) (c)\&(d)), and an Additional Protocol II conflict as modified by the Tadić Jurisdiction Appeal (Art. 8(2) (e)\&(f)). There appears to be no room for arguing before the ICC, as we do before the ICTY, that certain war crimes apply to all armed conflicts, regardless of classification. One interesting feature of the ICC Statute is Art. 8(1) which specifies that the court has jurisdiction in respect of war crimes "in particular when committed as part of a plan or policy or as part of a large-scale commission of such crimes". Certainly, plan, policy, and scale are not elements of war crimes under customary law. The killing of a single prisoner of war or the solitary rape of a woman in occupied territory is a war crime. Presumably, plan, policy, and scale are factors to be taken into account by the Prosecutor in determining whether or not to commence investigations against particular potential accused. Speaking for myself alone, I must also observe that some of the war crimes enumerated in the ICC Statute appear to be defined in an unnecessarily narrow fashion. For example, the unlawful attack provisions all refer to "intentionally" launching or directing attacks. We at the ICTY use "wilful" as our mental element as that is the language of the Additional Protocols and "wilful" incorporates both intention and a high degree of recklessness. One might query how a chamber of the ICC would respond to a defence argument that the accused may have attacked civilians but he didn't intend to do so, he was merely too busy fighting a war to devote any resources to determining where civilians were located.

\section{Crimes against humanity}

The concept of a crime against humanity is much more recent. Basically, it is a twentieth century development and its first application in a criminal setting, precipitated by the mistreatment by Germany and its allies of their own nationals or the nationals of their cobelligerents, is in the post World War II war crimes cases. In brief, under customary law, a crime against humanity is: (a) one of a list of prohibited acts, (b) committed as part of a widespread or systematic attack, (c) pursuant to or in furtherance of a state or organizational policy, (d) directed against any civilian population, (e) with knowledge of the attack. There is no requirement for the existence of an armed conflict. "Civilian" clearly excludes combatants but it should otherwise be given a very broad definition, including, for example, hospital patients and resistance fighters who have laid down their arms (Prosecutor v. Tadić, Case No. IT 94-1-T (ICTY Trial Chamber Opinion and Judgment 7 May 1997, paras. 639-43). There is no treaty devoted exclusively to crimes against humanity unless one regards genocide as an aggravated form of crime against humanity. 
The entire body of treaty law devoted to crimes against humanity, excluding genocide, would take up fewer than ten pages of the text of the normal law review.

The ICTY Statute addresses crimes against humanity in Art. 5. Under the ICTY Statute, as opposed to customary law, crimes against humanity must be committed "in armed conflict, whether international or internal in character". The ICC Statute is the first relatively widely ratified treaty text which, in its Art. 7, provides a relatively comprehensive definition of crimes against humanity, and of the different modalities by which such crimes may be committed. The ICC has jurisdiction over crimes again humanity committed in peace or war. Art. 7(2)(a) defines " attack directed against any civilian population" as "a course of conduct involving the multiple commission of acts referred I to in paragraph 1 (that is, the enumerated prohibited acts) against any civilian population, pursuant to or in furtherance of a State or organizational policy to commit such attack." Attack, for crimes against humanity purposes, is not the same thing as an attack in a combat context involving the use of force to seize or defend a position. For example, multiple acts of rape or torture could be an attack for crimes against humanity purposes. It is quite possible that Art. 7 of the ICC Statute constitutes a codification of customary international law.

As the various treaty or statutory provisions related to crimes against humanity do not explicitly refer to combat situations or to matters such as unlawful attacks or the use of unlawful weapons, one might query whether crimes against humanity should be applied to regulate what happens in combat. Until the creation of the ICTY, crimes against humanity charges were used in instances where the civilian victim group had been under the control of or in the hands of the group with which the perpetrator was linked. That is, such charges were used where the victims were in camps, in occupied territory, or in the national territory of the state or organization supporting or initiating the policy of attacking the civilian victim group. There is no necessary reason why this should be so. If the most significant elements of crimes against humanity are the widespread or systematic commission of acts directed against a civilian population, such acts can be committed at a distance as well as at close quarters. If the object of a policy is to kill or injure civilians, that policy can be implemented by rounding up and killing civilians in occupied territory or by bombing or shelling a city still under the control of the opposing side. Genocide, which might be regarded as the supreme crime against humanity, was directed at the Jewish people at Auschwitz and at the other Nazi death camps. It could also be committed by use of nuclear, bacteriological or chemical weapons directed against the people of Israel. The ICTY-OTP has, as a matter of practice, tended to use both war crimes charges (under Art. 3 of our Statute) and crimes against humanity charges (under Art. 5 of our Statute) to penalize the same course of conduct. Most of our cases have an underlying aspect of persecution just as most of the cases before our sister tribunal, the ICTR, involve genocide. For this reason, it is particularly important for us to determine the relationship between persecution charges and combat related charges such as unlawful attacks. If the ICC-OTP does decide to prosecute for combat crimes, you may well find yourselves facing similar problems, particularly if many of the situations brought before the ICC have a persecutory aspect.

\section{Unlawful attacks against civilians}

The ICTY-OTP has prosecuted unlawful attack charges in five cases to date. Trial judgments have been rendered in Blaskić, Kordić/Cerkez, and Galić. Trials are currently underway in Strugar and in Milosević. Blaskić and Kordić/Cerkez were trials involving Bosnian-Croat accused and incidents in the Lasva River Valley in Bosnia, in particular the Ahmici massacre in which many of the inhabitants of a small Bosnian village were killed 
when it was overrun by Bosnian-Croat forces. Galić was the commander of Bosnian-Serb forces involved in a protracted shelling and sniping campaign against the inhabitants of Sarajevo. Strugar was the commander of Yugoslav National Army Forces engaged in what the prosecution alleges was the unlawful shelling of the Old Town of Dubrovnik on 6 December 1991. Milosević is charged with responsibility for a wide range of offences including offences related to what happened in Sarajevo and in Dubrovnik. By far the most elaborate and thoughful judicial decision ever rendered in connection with unlawful attacks is the Galić decision and I will focus on it in my comments.

In combat situations, IHL can almost be reduced to one basic principle, the principle of distinction. In the conduct of military operations, military forces are obligated to distinguish between military objectives (people or things) and civilians and civilian objects and to direct their efforts against military objectives. People are military objectives when they are combatants, that is, members of the armed forces other than medical or religious personnel, or civilians who take a direct part in hostilities. The category of civilians taking a direct part in hostilities is very narrowly construed. Everyone else is a civilian entitled to protection from attack. Things are military objectives when they are objects which "by their nature, location, purpose or use make an effective contribution to military action and whose total or partial destruction, capture or neutralization, in the circumstances ruling at the time, offers a definite military advantage" (AP 1 Art. 52(2)). There is a substantial debate in IHL circles concerning whether or not the AP1 definition of military objective codifies customary law, although most would agree it does, and concerning what its scope is. The content of that debate is more appropriately the topic of discussion for another presentation. It is extremely relevant when one is considering high tech warfare or air warfare. For example, it was important to us at the ICTY-OTP when we were concerned with reviewing the 1999 NATO bombing campaign over Yugoslavia. Our cases to date have involved ground warfare and, generally speaking, military objectives have been military facilities, paramilitary facilities, and a few key industrial sites or transportation or communications nodes.

A usable resume of the legal restrictions imposed upon the law-sensitive general would be:

(a) Weapons and methods of war which are prohibited are not used. When there are restrictions which apply to particular weapons and methods of war, these restrictions are complied with.

(b) Attacks are always directed against military objectives. When attacks are launched against military objectives:

(i) precautions are taken to identify the objective correctly;

(ii) precautions are taken to identify and quantify the risk to civilian persons and objects; and

(iii) precautions are taken to minimize incidental civilian casualties and damage to civilian objects.

(c) Attacks are not launched against military objectives if they may be expected to cause excessive/disproportionate injury to civilians or damage to civilian objects.

It must be noted that an attack is not unlawful per se every time civilians are killed or injured or civilian objects are damaged. What is prohibited are attacks directed against civilians or civilian objects and attacks which, although they are directed against military objectives, may be expected to cause excessive or disproportionate injury or damage to civilians or civilian objects. Once again, the meaning and scope of the principle of proportionality is an appropriate topic for another presentation. What should be noted here 
is that, frequently, and particularly in urban areas, military objectives are not conveniently separated from civilians and civilian objects. What must also be noted is that, except perhaps for properly maintained and aimed pistols and rifles, projectiles are not delivered with pin point accuracy. Except in unusual cases, it will not be practicable to reason inexorably from the fact that civilians have been killed or injured or that civilian property has been damaged to the conclusion that the actus reus of an offence has been committed. An assessment of the surrounding facts will be essential to determine, among other things, whether or not the intended target was a military objective and whether or not the incidental damage or injury actually was or could be expected to be disproportionate.

As opposed to the ICC Statute, the ICTY Statute does not list unlawful attacks against civilians as enumerated offences. As a result, we at the ICTY must charge unlawful attacks as unenumerated offences under Art. 3. Further, since the Tadić Jurisdiction Appeal Decision has provided us with the basis for arguing that certain offences have a substantially similar legal content in both international and internal conflicts, we have developed and defended unlawful attack charges which are common to all conflicts. To give our most recent example, in the Strugar case which is now at trial, our charges include:

Count 3: Attacks on civilians, a Violation of the Laws or Customs of War, as recognized by Article 51 of Additional Protocol I and Article 13 of Additional Protocol II to the Geneva Conventions of 1949, punishable under Articles 3 and 7(1) and 7(3) of the Statute of the Tribunal.

In order to evade the conflict classification issue, the ICTY-OTP has rooted its unlawful attack on civilians charges in identically worded provisions of API and APII. API Art. 51(2) and APII Art. 13(2) both state in part: "The civilian population as such, as well as individual civilians, shall not be the object of attack." API, however, goes on to refer to other forms of unlawful attack. In particular, Art. 51 refers to indiscriminate attacks, including disproportionate attacks, and refers to five forms of such attack, all of which are prohibited. In addition, Art. 85 contains grave breach provisions relating to unlawful attacks. By contrast, APII has no provisions related to unlawful attacks on civilians beyond the single sentence in Art. 13(2) quoted earlier. ICTY-OTP practice has been to focus on the common sentence in API Art. 51(2) and APII Art. 13(2) and to argue that proof of the occurrence of the various types of indiscriminate attacks, including disproportionate attacks, may provide an evidentiary basis for the trial chamber to draw an inference that the attacks were, in substance, directed against the civilian population. In other words, we argue that the essential substance of the detailed API provisions concerning unlawful attacks applicable to international conflicts is also contained in the single relevant sentence in APII which is applicable to internal conflicts. This is a conscious effort on our part, successful to date, to argue that the law concerning unlawful attacks against civilians is, in substance, the same in both international and internal conflicts.

The most thoughtful and elaborate decision to date by an ICTY chamber concerning unlawful attack charges against civilians is the Galić Trial Chamber decision issued on 5 Dec 2003. In Galić, the Trial Chamber accepted that the mental element for the offence was "wilful" and accepted that the approach taken in the grave breach provisions of API was appropriate. Specifically, the Trial Chamber held:

"54... The Commentary to Article 85 of Additional Protocol I explains the term as follows:

wilfully: the accused must have acted consciously and with intent, i.e., with his mind on the act and its consequences, and willing them ('criminal intent' or 'malice aforethought'); this encompasses the concepts of 'wrongful intent' or 'recklessness', 
viz., the attitude of an agent who, without being certain of a particular result, accepts the possibility of it happening; on the other hand, negligence or lack of foresight is not covered, i.e., when a man acts without having his mind on the act or its consequences. (ICRC Commentary para 3474).

The Trial Chamber accepts this explanation, according to which the notion of "wilfully" incorporates the concept of recklessness, while excluding mere negligence. The perpetrator who recklessly attacks civilians acts "wilfully"."

The Trial Chamber then goes on to decide in para 56 that the elements for the charge are the elements common to offences under Art. 3 of the Statute and the following specific elements:

"1. Acts of violence directed against the civilian population or individual civilians not taking direct part in hostilities causing death or serious injury to body or health within the civilian population.

2. The offender wilfully made the civilian population or individual civilians not taking direct part in hostilities the object of those acts of violence."

It then goes on to indicate in para 57 that "indiscriminate attacks, that is to say, attacks which strike civilians or civilian objects and military objectives without distinction, may qualify as direct attacks against civilians."

The general comments of the Galic Trial Chamber on the proportionality issue should also be noted:

"58. One type of indiscriminate attack violates the principle of proportionality. The practical application of the principle of distinction requires that those who plan or launch an attack take all feasible precautions to verify that the objectives attacked are neither civilians nor civilian objects, so as to spare civilians as much as possible. Once the military character of a target has been ascertained, commanders must consider whether striking this target is "expected to cause incidental loss of life, injury to civilians, damage to civilian objectives or a combination thereof, which would be excessive in relation to the concrete and direct military advantage anticipated." If such casualties are expected to result, the attack should not be pursued. The basic obligation to spare civilians and civilian objects as much as possible must guide the attacking party when considering the proportionality of an attack. In determining whether an attack was proportionate it is necessary to examine whether a reasonably well-informed person in the circumstances of the actual perpetrator, making reasonable use of the information available to him or her, could have expected excessive civilian casualties to result from the attack."

Two footnotes to this para should also be noted:

"108. The ICRC Commentary acknowledges that "the disproportion between losses and damages caused and the military advantages anticipated raises a delicate problem; in some situations there will be no room for doubt, while in other situations there may be reason for hesitation. In such situations, the interests of the civilian population should prevail". ICRC Commentary, para 1979."

"109. The Trial Chamber notes that the rule of proportionality does not refer to the actual damage achieved by an attack, but instead uses the words "expected" and "anticipated"" The footnote goes on to observe that several states made statements 
of understanding on ratifying API to the effect that "the decision taken by the person responsible has to be judged on the basis of all information available to him at the relevant time and not on the basis of hindsight."

No tribunal to date has ever explicitly determined in a well articulated manner in a close case that disproportionate damage was caused during an attack on a military objective. The Galic Trial Chamber was, however, compelled to grapple with the issue in its discussion of one shelling incident, the shelling of the Dobrinje football tournament on 1 June 1993. In that incident, about 200 spectators, including women and children, were watching a football game in the corner of a parking lot which was bounded on three sides by 6-storey apartment blocks and on the fourth by a hill. Two shells exploded in the parking lot killing between 12 and 16 persons and wounding between 80 and 140 persons. The players and many of the spectators were military personnel and, as such, military objectives. The Commander of the $\mathrm{ABiH} 5^{\text {th }}$ Motorized Dobrinja Brigade, to which the soldiers belonged, filed a report indicating there were 11 killed and 87 wounded (6 combatants killed and 55 wounded, 5 civilians killed and 32 wounded) (para 377). There is a strong possibility that there were more military casualties than civilian casualties. Although assessing proportionality is not a simple exercise in number crunching, it would be difficult to conclude that, in this incident, there were disproportionate civilian casualties unless one makes the arbitrary determination that civilian lives count for more than military lives.

The majority of the chamber finessed the requirement to assess the proportionality of the result by focusing on the mens rea of the perpetrators and on the fact that civilian casualties were caused. "387. ... Although the number of soldiers present at the game was significant, an attack on a crowd of approximately 200 people, including numerous children, would clearly be expected to cause incidental loss of life and injuries to civilians excessive in relation to the direct and concrete military advantage anticipated..."

Generally speaking, unlawful attack cases will involve multiple incidents of shelling or sniping. In the Galic case, hundreds of civilians were killed or wounded in Sarajevo by shelling or sniping during the period covered by the indictment, 1992-94. Quite obviously it would be impossible to treat each incident of killing as a separate murder case. Some way must be developed to get from the specific incident at the micro level to what was alleged to be an unlawful shelling or sniping campaign at the macro level. Indeed, the link from the micro to the macro level was essential to the case. If, for example, the prosecutor can prove with a degree of precision in a manageable time that 20 sniping incidents have occurred over a two year period when the accused is responsible for 15000 soldiers in the front lines, in the absence of direct evidence of relevant orders being given, would a reasonable court conclude that the commander bears command responsibility for the sniping or that he must have ordered such acts? On the other hand, if the prosecutor can establish both the occurrence of the 20 incidents and an adequate link to what appears to be a much broader crime base, it is much easier for the court to reach such conclusions. Presumably the preferred approach would be to determine in some scientifically valid fashion the entire apparent crime base, for example, it appears from sound medical evidence that 1000 civilians have been killed by sniper fire from forces under the command of $\mathrm{X}$, and then to pick a statistically valid sample on something like a random numbers basis for more detailed examination. Detailed evidence concerning all cases in the sample group would then be put before the court. If that is done, or if the prosecutor makes the court aware of cases in the sample group which do not indicate unlawful acts occurred, then, perhaps, the court can conclude, for example, that $70 \%$ of the cases in the sample group constitute crimes therefore $70 \%$ of the larger group also constitute crimes therefore a campaign of unlawful sniping occurred. 
Desirable as the mathematical/scientific approach might be, it is not always practicable and it was not practicable in the Galić case. The Galić prosecution team listed scheduled sniping and shelling incidents as "representative allegations" in annexes to the indictment. These incidents were not chosen on any scientific or random numbers basis. They were chosen because they were perceived to be the best from a prosecution point of view. The prosecution also introduced evidence of unscheduled incidents, survey or impressionistic evidence, and solid demographic evidence which could adequately establish cause of death or injury but which could not, of itself, establish whether the death or injury was the result of unlawful acts.

The majority of the Trial Chamber held that a campaign of military actions in the area of Sarajevo involving widespread or systematic shelling and sniping of civilians resulting in civilian death or injury existed alongside a lawful military campaign directed against military objectives (para 583). Civilians were directly or indiscriminately attacked and, at a minimum, hundreds of civilians were killed and thousands of others were injured (para 591).The reasons for this finding included:

(a) no civilian activity and no areas of Sarajevo held by the $\mathrm{ABiH}$ seemed to be safe from sniping or shelling attacks from SRK-held territory (para 584),

(b) indeed specific areas of the city became notorious as sources of sniper fire directed at civilians (para 585),

(c) although civilians adapted to the environment by taking precautionary measures, they were still not safe from deliberate attack (para 586),

(d) the evidence of residents of Sarajevo and of victims was upported by the evidence of international military personnel (para 587),

(e) although there was some evidence that $\mathrm{ABiH}$ forces attacked their own civilians to attract the attention of the international community, that stray bullets may have struck some civilians, and that some civilians were shot in the honest belief they were combatants, "The evidence in the Trial Record conclusively establishes that the pattern of fire throughout the city of Sarajevo was that of indiscriminate or direct fire at civilians in AbiH-held areas of Sarajevo from SRK-controlled territory not that of combat fire where civilians were accidentally hit."(para 589), and

(f) fire into AbiH-held areas of Sarajevo followed a temporal pattern (para 590).

In your cases before the ICC, of course, the analogous offences to our unlawful attack offences would be Art. 8(2)(b)(i) (intentionally directing attacks against civilians in international conflicts), Art. 8(2)(b)(iv) (intentionally launching an attack in an international conflict in the knowledge that it will cause incidental losses "which would be clearly excessive in relation to the concrete and direct overall military advantage anticipated"), and Art. 8(2)(e)(i) (intentionally directing attacks against civilians in internal conflicts). These offences and their related elements are not precisely the same as ours. In particular: (a) the mental element differs - ours, derived from the APs is "wilful", yours is "intentional", (b) the physical elements differ- ours, derived from the APs require proof of loss, yours do not although, presumably, in most cases a charge would not be brought unless there was actual loss and, in any event, proof of loss is usually very helpful in proving the mental element, (c) your proportionality standard " clearly excessive in relation 
to the concrete and direct overall military advantage anticipated" appears to be higher than ours which omits the underlined words, and (d) on the face of the Statute, you do not appear to have a way to charge for disproportionate attacks in internal conflicts. Of course, over time, you may find that your mental element and your proportionality standard are, in practice, similar to ours. Since, all too often, military objectives, civilians, and civilian objects are located side by side, you may also find that our argument that disproportionate attacks can become attacks directed against civilians may become quite helpful for cases involving unlawful attacks in internal conflicts.

\section{Persecution}

A variety of war crimes and crimes against humanity can be committed in a combat setting. In the ICTY, perhaps because we have no statutory doctrine of included offences, and also out of an abundance of caution and because our chambers have accepted cumulative charging, we have tended to err on the side of over charging rather than under charging. Focusing exclusively on offences involving death or injury in combat, in addition to unlawful attacks we have charged the crimes against humanity of persecution, murder, and inhumane acts other than murder (to cover wounded victims). We have also charged the following unenumerated violations of the laws or customs of war under Art. 3 of our Statute, unlawfully inflicting terror upon civilians, murder, and cruel treatment (to cover wounded victims). It should be noted that, as a general statement, we have not charged for grave breaches of the Geneva Conventions related to killing or wounding because protected persons under the Geneva Conventions, particularly civilians and prisoners of war must be "in the hands of " the party to the conflict committing the grave breach. Usually this means they must be in occupied territory or otherwise under the control of the party inflicting the injury. An inhabitant of Dubrovnik being shelled by Yugoslav forces would not be "in the hands of" Yugoslavia. It is clear that victims of crimes against humanity need not be "in the hands of " the party mistreating them. The ICTY-OTP has adopted the position, which has been maintained by the chambers, that there is no "in the hands of " requirement for victims of our violations of laws or customs of war charges.

At the ICC-OTP you have yet to decide upon your charging practices. It may, of course, be that you see no need for multiple charges related to the same incident. Concerning your war crimes offences, you would have the same concerns about protected persons status and "in the hands of" for your grave breach offences under Art. 8(2)(a), you may, however, wish to charge for killing or wounding in combat related incidents in internal conflicts under Art. $8(2)$ (c). In addition, you may have reason to prosecute for killing or wounding in combat related incidents as crimes against humanity under Art. 7(a) (murder), 7(b) (extermination), 7(h) (persecution) or 7(k) (other inhumane acts).

As it is the most interesting example of potential overlap with unlawful attacks, I will focus in this presentation on the crime against humanity of persecution as it has been applied before the ICTY and as it might be applied before the ICC. Just as genocide has become the offence which best represents what happened in Rwanda during 1994 so the crime against humanity of persecution has come to typify what happened in the territory of the former Yugoslavia. For the most part, perpetrators did not necessarily wish to annihilate the members of other groups residing in certain areas but they did wish to make these areas ethnically pure. To ethnically cleanse these areas they were prepared to use a wide range of persecutory means. As a result, the persecution charge has been addressed in many ICTY decisions. 
Before the ICTY, in addition to the common elements necessary for all crimes against humanity, the requisite elements for a persecution count are (a) a persecutory act (b) committed on political, racial or religious grounds (c) by an accused with the requisite discriminatory mental state. The Kupreskić Trial Chamber defined persecution (at para 621) as "the gross or blatant denial, on discriminatory grounds, of a fundamental right, laid down in customary or treaty law, reaching the same level as the other acts prohibited in Article 5." Art. 5, of course, is concerned with crimes against humanity. A reading of the Tadic Trial Judgment (para 713) and the Tadic Appeals Judgment (para 305) indicates that all of the crimes enumerated in Art. 2, 3, and 5 can, if the common elements for crime against humanity counts and the discriminatory mental state requirement are met, provide the basis for a persecution count. The Kvocka Trial Chamber held:

"186. Thus far, the Trial Chambers of the ICTY have found that the following acts may constitute persecution when committed with the requisite discriminatory intent: imprisonment, unlawful detention of civilians or infringement upon individual freedom, murder, deportation or forcible transfer, 'seizure, collection, segregation and forced transfer of civilians to camps', comprehensive destruction of homes and property, the destruction of towns, villages and other public or private property and the plunder of property, attacks upon cities, towns and villages, trench-digging and the use of hostages and human shields, the destruction and damage of religious or educational institutions, and sexual violence."

The Trial Chamber then went on to find (para 192) that harassment, humiliation, and psychological abuse of detainees could meet the actus reus requirements for persecution.

What should be noted at this point is that "murder" and "attacks upon cities, towns and villages " have been regarded as meeting the actus reus requirements for persecution before the ICTY. Further, the crime against humanity of persecution under Art. 7(1)(h) of the ICC Statute is broader than its ICTY equivalent. The discriminatory grounds are broader. The ICC crime need not occur during armed conflict. "Persecution" is defined in Art. 7(2)(g) as "the intentional and severe deprivation of fundamental rights contrary to international law by reason of the identity of the group or collectivity." At a minimum, the scope of "persecutory acts" under the ICC Statute would appear to be as broad as the scope of "persecutory acts" under the ICTY Statute as elaborated upon by the Kupreskic Trial Chamber "the gross or blatant denial... of a fundamental right, laid down in international customary or treaty law, reaching the same level of gravity " as other acts prohibited as crimes against humanity. Bearing in mind the scope of persecution under the ICC Statute and the fundamental importance of the right to life, it is conceivable that you at the ICC might also eventually find yourselves with unlawful attack charges under Art. 8, and both "murder" and "attacks upon cities, towns and villages" specifications to a persecution charge under Art. 7, all in relation to a single combat incident. How do you reconcile the various counts? At least as important, what do you have to prove if you decide to avoid multiple charges and go with persecution alone?

\section{Reconciling unlawful attack charges and persecution charges (and other charges too)}

We do not contribute to the viability of IHL by indulging in creative reclassification so that an act which is regarded from one perspective is lawful can be regarded as unlawful because we changed the label. Where the crime base consists of shelling or sniping incidents in a combat environment, it is essential to prove that death, injury or damage was caused by an unlawful attack, that is, one directed against civilians or civilian objects or one directed against a military objective which may be expected to cause disproportionate 
incidental losses, before moving on to determine whether the additional elements necessary to establish the commission of other offences have also been established. If the attack was not unlawful then the resultant death, injury or damage is not unlawful. If a civilian is killed or injured during an attack on a military objective which was not expected to result in civilian casualties or damage to civilian objects disproportionate to the expected military advantage then no crime has been committed. This is so even if there is an expectation that, unfortunately, some civilians will be killed or injured during the attack. There is no basis for a crime against humanity charge because the attack was directed against a military objective, not against civilians or civilian objects. There is no basis for a war crimes charge of murder because the mens rea is lacking. The unlawful attack foundation is essential to the assessment of legality even if there is no unlawful attack charge relating to a particular combat related incident. We can not avoid the issue by simply avoiding the charge. Quite clearly there can be incidents in which it is so clear that the attack is directed against civilians that one can proceed with a persecution count or a war crime or crime against humanity count of murder. Even in such circumstances, however, it is essential that the prosecutor and the chamber take into account the unlawful attack elements, at least implicitly, before coming to the conclusion that counts charged have been proven.

A, regrettably somewhat opaque, example of the overlap between unlawful attack and persecution counts is contained in the Blaskić Trial Chamber decision. The village of Donja Veceriska is located on a hill about one and one-half kilometers northwest of the town of Vitez in Bosnia. It was occupied by Bosnian Muslims and some $\mathrm{ABiH}$ forces in April 1993 and it overlooked the Croatian controlled SPS explosives factory, a significant military objective. Bosnian Croat forces attacked the village on 16 Apr 93. The Trial Chamber held:

"543... It was not able to characterise the attack as being directed only against a civilian population. Consequently, until the Muslim's retreat on the morning of 18 April, the conflict at Donja Veceriska was characterised as a conflict between the $\mathrm{HVO}$ and independent Croatian units on the one hand and the $\mathrm{AbiH}$ on the other. Before the retreat of the Muslims, it was not clear that the criteria of proportionality of a military attack against positions defended by the military had not been met as regards the destruction of property, nor that the injuries to Hadzira Basic and the deaths could not be considered the result of a conflict between the AbiH and the HVO." (The Trial Chamber did go on to assign responsibility to Blaskic for things that happened after the HVO took control of the village.)

The Galic Trial Chamber applied the approach that proof of an unlawful attack was a prerequisite for proof of other offences related to shelling or sniping but it did so without enthusiasm:

"144. The Prosecution submits that, in the context of an armed conflict, the determination that an attack is unlawful in light of treaty and customary international law with respect to the principles of distinction and proportionality is critical in determining whether the general requirements of Article 5 have been met. Otherwise, according to the Prosecution, unintended civilian casualties resulting from a lawful attack on legitimate military objectives would amount to a crime against humanity under Article 5 and lawful combat would, in effect, become impossible. It therefore submits that an accused may be found guilty of a crime against humanity if he launches an unlawful attack against persons taking no active part in the hostilities when the general requirements of Article 5 have been established. The Trial Chamber accepts that when considering the general requirements of Article 5, the body of laws of war plays an important part in the 
assessment of the legality of the acts committed in the course of an armed conflict and whether the population may be said to have been target as such."

Although the endorsement of the ICTY-OTP approach is tepid at best, we think this approach is legally sound and contributes to the continued viability of IHL.

In conclusion, I would like to make an observation on a related issue involving combat and crime. The OTPs of international tribunals prosecute crimes involving thousands of victims and participants and horrifying events. Although our statutes compel us to focus on individual criminal responsibility, it is all too easy for us to conclude that everyone knew what was happening, that everyone must have participated in some way, and that everyone must be guilty. If we adopt that approach in our work, we will destroy the law we came to save. It is essential for us to draw boundaries, to set limits so that guilt or innocence is dependent on something more than the discretionary decision of the Prosecutor to investigate or prosecute. I concede I am a former military lawyer and I may, as a result have a trade union mentality on such matters. I would suggest, however, that it is essential to distinguish between soldiers engaged in legally permissible combat activities and those responsible for crimes with which we must deal. Asserting, for example, that soldiers on one side (maybe both on occasions) are occupying territory so that ethnic cleansing may be carried out and, therefore, all of their combat activities are unlawful is legally erroneous and contributes to the destruction of IHL as, if all the soldiers on one side are criminals in any event, there is no incentive for them to comply with the law. Some of the soldiers, or their commanders, may be aiding and abetting a persecution count related to ethnic cleansing. Their combat activities as such, however, do not become unlawful. To use a domestic example, if I drive A to the airport where he shoots B, I may, depending on my mental state, bear some criminal responsibility for the shooting of B. My act of driving is not, however, in and of itself, unlawful. 
Mr. Fenrick has been a Senior Legal Adviser in the Office of the Prosecutor of the International Criminal Tribunal for the Former Yugoslavia since 1994. Until recently, he was the head of the Legal Advisory Section. He is now the Senior Adviser on Law of War Matters. At the ICTY, he has provided international law advice to the OTP and argued at the trial and appeal levels, particularly on matters related to conflict classification and command responsibility. He was also the main author of the Report to the Prosecutor on the 1999 NATO Bombing Campaign against Yugoslavia. Immediately prior to coming to the ICTY he was a member of the SCR 780 Commission of Experts investigating war crimes allegations in the former Yugoslavia and, as such, he was responsible for legal matters and for on-site investigations. He was a military lawyer in the Canadian Forces from 1974 to 1994, specializing in law of war and operational law matters. He has published widely on law of war matters and his publications have been cited by the ICTY and the Supreme Court of Canada. 